\title{
細線熱電対を用いた回復温度測定に基づく準非侵襲な 軸対象音速ノズル内遷音速流速分布の測定
}

\author{
石 橋 雅 裕*・高 本 正 樹*
}

\begin{abstract}
Ouasi-Non Intrusive Measurement of the Transonic Flow Field in an Axi-Symmetric Critical Nozzle Based on Recovery Temperature Measurement Using a Thin Thermocouple
\end{abstract}

\author{
Masahiro IshiBashi*, Masaki TAKAмото*
}

\begin{abstract}
Flow velocities from several $\mathrm{m} / \mathrm{s}$ to supersonic of a gas having a Prandtl number different from unity were measured based on the recovery temperatures measurement using a very thin thermocouple, which produced almost no disturbance in the field. Very high space resolution in the $10 \mu \mathrm{m}$ order as well as very small disturbance from the supports of the thermocouple wire were achieved because the sensing point of a themocouple wire was concentrated exactly at the contact point, which allows to use a long thermocouple wire to locate its supports far away from the measuring point.

A thermocouple wire of $50 \mu \mathrm{m} \phi$ accompanied with a traversing system was settled through an axi-symmetrical critical nozzle with a throat diameter of $13.4 \mathrm{~mm} \phi$ to measure the velocity field in the nozzle. The results agreed quite well with the one-dimensional isentropic theory even qualitatively as well as they showed the fine structure predicted by the two-dimensional isentropic theory. Furthermore, the results revealed complicated flow structures, which were unpredictable by these simple theories, such as oblique shocks and normal shock whose amplitude and location changed depending on the back pressure ratio applied on the nozzle in a complicated manner.
\end{abstract}

Key Words : axi-symmetric transonic flow field, Prandtl number, recovery temperature, shock wave, flow velocity measurement

\section{1.はじめに}

亜音速, 超音速，また，その両方を含む遷音速流れの流速 分布測定は，さまざまな分野で重要な役割を果たしている. そのため,これまでにさまざまな測定方法，たとえば，古く はピトー管やシュリーレン写真, 近年では熱線流速計やレー ザーを応用した LDV, PIV, CARS, LIF 等々が開発されて きたが，一般的な温度センサーを用いて流れ場を測定するこ とは行なわれてこなかった。 その理由は, 流れ場中に静止し て設置された温度センサの回りには境界層が発生してセンサ 表面での流速が 0 となり，一般的な気体のプラントル数がほ ぼ1であるために, 温度が流速に依存しないよどみ点温度に 戻ってしまうと考えられていたためである.この単純化され た考察により, 温度測定に基づいて流れ場の変化を検出する ためには, 流れと共に温度センサーを移動させなければなら ない, すなわち不可能であると考えられてきた. CARSや

\footnotetext{
* 計量研究所 力学部 流体計測研究室 つくば市梅園 1-1-4 (現産業技術総合研究所)

* Mechanical Metrology Department, National Research Laboratory of Metrology 1-4 Umezono 1, Tsukuba (Received September 26, 2000)

(Revised April 27, 2001)
}

LIF は，感温トレーサを流すことによりこの点を解決してい る。

しかし，温度センサが固定されている場合でも，実際の気 体では速度境界層と温度境界層の厚さが違うため, 流速がゼ ロとなっても壁面温度がよどみ点温度まで回復しない。その 回復の大きさは, 静温度降下に回復温度係数をかけた值とな り流速に依存するため, これを利用した流速測定が可能とな るはずである.一般的に用いられる断熱壁の回復係数 ${ }^{1)}$, すな わちプラントル数 $\operatorname{Pr}$ の平方根 $\sqrt{P r}$ を用いて試算すると,た とえば, よどみ点が $27 \sim 29^{\circ} \mathrm{C}$ 空気が流れる管路の臨界点で は静温度がよどみ点より $50 \sim 51^{\circ} \mathrm{C}$ 降下し，この位置で流速を ゼロとすると, 空気のプラントル数が 0.713 であるために静

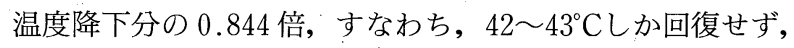
壁面には $7.7 \sim 7.9^{\circ} \mathrm{C}$ 温度降下が発生することになる.この 温度差は, ごく一般的な熱電対でも十分に分解可能な大きさ である。

近年, 香川 (2) $^{2}$, 細線熱電対の高速応答に着目し, 管内の 非定常流れにおける温度変動を測定した. これに対し, 筆者 らは, 細線熱電対のもたらす流れ場の乱れが非常に小さいこ とに着目し，流れ場の中に張った熱電対線をトラバースする ことにより，軸対象音速ノズル内の遷音速流速分布をほぼ非 
侵襲に測定したので，その結果について述べる。

本測定から得られる結果は, 一見すると, 熱線流速計から 得られるものとほとんど同じに見えるが，つぎに述べるいく つかの決定的な差がある．まず第一に，測定体積が接点の大 きさに限定されるため, 非常に高い空間分解能が達成できる 点である.その大きさはほぼ直径で決まる大きさとなるため, たとえば $50 \mu \mathrm{m} \phi$ の線を用いれば $50 \mu \mathrm{m}$ 程度の空間分解能 が達成される。また, 熱線流速計では, 空間分解能を維持す るために長い熱線を用いることができないが，本方法では， 接点に至るまでの長さが測定值に影響しないため, 長い熱電 対線を用いることにより, 高い空間分解能を維持したままサ ポート位置を測定点から十分に離すことができる.さらに, 1 つ付け加えれば, 熱電対線を通すことができれば測定可能 となるため, 空間分解能が高いことと相まって, mm オーダー の流路直径における流速分布測定も可能となる点である.し たがって，大半の測定対象について，二次元モデルや空を用 いることなく, 対象そのものについての測定が可能となる.

本論文では, 主に, スロート直径 $13.4 \mathrm{~mm}$ の音速ノズルを 測定対象とする，そのため，スロート面積に対する細線熱電 対の断面積の比は ppm オーダーとなり, その幾何学的影響は まったく無視できる。しかし, 熱電対線の回りに発生する境 界層による大きな乱れの可能性もあるため, 先に報告した音 速ノズルの直列試験法 ${ }^{3)}$ を用い，音速ノズルのもつとも敏感 なパラメータである流量を用いて乱れの有無を監視した。そ の結果, 熱電対やサポートの有無, また, これらのトラバー スによる流量変化はまったく観測されず，測定はほぼ非侵襲 であるとみなされた。

本論文では，はじめに測定原理を述べ，つぎに亜音速域で 感度を測定して本方法による流速測定が可能であることを示 し, 最後に, 音速ノズル内の流速分布を測定した結果を示し, 理論值と非常に良く一致するばかりか, 単純な理論では予測 できないさまざまな現象が検出できることを示す.

\section{2. 測 定原理}

マッハ数が $M$, 静温度が $T$ である流れの中に, 管路に固定 された温度センサが挿入されている場合を考える。センサ周 りには境界層が発生し，センサ表面での流速はゼロとなる。 センサは, 接している気体の温度を示すため, 気体のプラン トル数を $P r$, 比熱比を $x$ とすると, 回復温度

$$
T_{r}=\left\{1+f(P r) \cdot \frac{x-1}{2} \cdot M^{2}\right\} \cdot T
$$

を示すはずである.ここで, $f(P r)$ は, プラントル数 $\operatorname{Pr}$ の関 数で回復係数と呼ばれ，Pr=1のときに 1 となる.したがっ て, $\operatorname{Pr}=1$ では回復温度はよどみ点温度に等しく, 断熱管路 ではいかなる位置においても同じ温度が示される. Pr $<1$ の 場合は，温度境界層が速度境界層より厚くなり壁面温度が下 がるため, 温度センサは, 静温度降下の $\{1-f(P r)\}$ 倍だけよ どみ点より低い温度を示し，流速に依存して変化する。

関数 $f(P r)$ の形は主に実験により求められるが, 非常に細
い線にそのまま適用できるものはない：そのため，本論文で は, 流れ方向に向く断熱円筒管の表面に発生した層流境界層 における回復係数 ${ }^{4)}$

$$
f(P r)=\sqrt{P r}
$$

を用いて解析する．この係数は境界層厚さが円筒管直径に比 べて十分小さいことを前提としているが，後に示すように， これを用いて求めた回復温度は測定值とよく一致する。

よどみ点温度 $T_{0}$ と静温度の間には, 流れが断熱であれば,

$$
T_{0}=\left(1+\frac{x-1}{2} \cdot M^{2}\right) \cdot T
$$

の関係があるため，(1)〜 ( 3 ) 式から回復温度とよどみ点温 度の差である回復温度降下 $\Delta T_{r 0}$ を計算することができる.

$$
\Delta T_{r 0} \equiv T_{r}-T_{0}=-(1-\sqrt{P r}) \cdot \frac{x-1}{x+1} \cdot T_{0} \cdot M^{*^{2}}
$$

ここで， $M^{*}$ は, 臨界音速 $a^{*}$ に基づいたマッハ数

$$
M^{*}=\frac{|\mathbf{u}|}{a^{*}}
$$

であり，流速に比例する．空気のプラントル数は，温度と圧 力の依存性がほとんどなくほぼ定数であるため5)，(4)式は, 回復温度降下の大きさが流速の自乗に比例することを示して いる.したがって, 回復温度降下分布の単純なプロットは, 十分に良く流れ場の様子を定性的に表わしている.

以上の解析には等エントロピーの仮定が入っていないた め, たとえば衝撃波がある流れでも，管路が断熱であれば流 れ全体にわたって (4)式が成り立ち, 本方法による流速測定 は有効となる。

\section{3. 被試験音速ノズル}

測定対象としたノズルは，Fig. 1 に示すように，ISO 9300 に準拠するトロイダルスロート型ノズル(以下,ベンチュリ型 ノズルと呼ぶ), または, そのスロートの位置で切ったノズル （以下，四分円型ノズルと呼ぶ）である。ノズルの製作は，研 磨を行わずに鏡面加工が可能となる超精密旋盤により行われ たため, 平均表面粗さが $0.04 \mu \mathrm{m}$ 程度であるにもかかわら ず, $1 \mu \mathrm{m}$ 程度以下の形状誤差が達成された ${ }^{6)}$.

臨界面積が $A^{*}$ である一次元等エントロピー流れにおける 流路面積とマッハ数の関係式

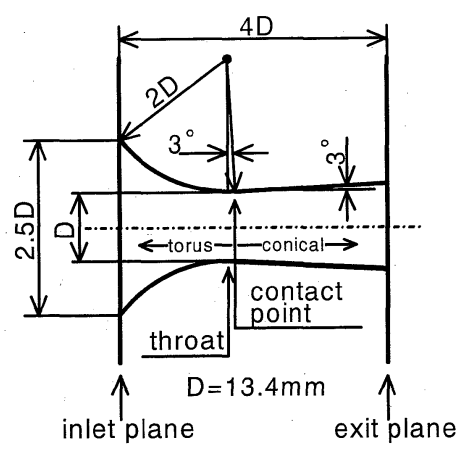

a)

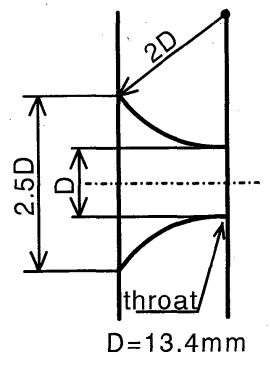

b)
Fig. 1 Design of the nozzle under test. a) Venturi nozzle and b) quadrant nozzle 


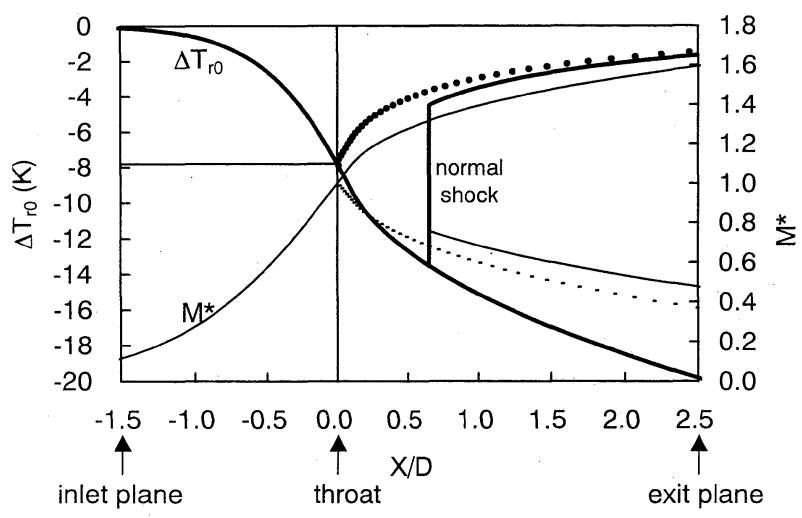

Fig. 2 The recovery temperature drop calculated with the assumption of one-dimentional isentropic flow in the nozzle shown in Fig. 1 a. The critical Mach number distribution is also plotted

$$
\frac{A}{A^{*}}=\frac{1}{M^{*}}\left[1-\frac{\varkappa-1}{2} \cdot\left(M^{* 2}-1\right)\right]^{-\frac{1}{\kappa-1}}
$$

と(4)式を用い, ベンチュリ型ノズル内の回復温度降下 $\Delta T_{r 0}$ とマッハ数 $M^{*}$ の分布を計算した結果を Fig. 2 に示 す.気体は空気とし，よどみ点温度を $27.0^{\circ} \mathrm{C}, \varkappa=1.400, P r$ $=0.713$ とした. 図の点線は, スロートでは音速が達成されて いるがその他では亜音速である場合を示し，実線は，ディ フューザの一部で超音速が達成されその後に垂直衝撃波が発 生する場合の一例，および，ディフューザ内の全域で超音速 になる場合を示している。これより, $0.1^{\circ} \mathrm{C}$ 程度の分解能をも つ一般的な熱電対を用いれば，スロートの十分前から回復温 度分布の測定が可能であることがわかる。

\section{4. 亜音速域における感度の測定}

第 2 節の解析が正しいことを確認するために, ベンチュリ 型ノズル内に熱電対線を張り，接点をほぼスロート中心に置 き，ノズルにかかる背圧比により温度がどのように変化する かを調べた. 背圧比(下流圧/上流圧) が 1 に近く流れが亜音速 の場合は, 背圧比を下げると流速が増加し温度が下がるが, 背圧比がノズルの臨界背圧比に達すると流速が音速に達し, それ以上背圧比を小さくしても同じ流速に保たれ温度も一定 となるはずである。

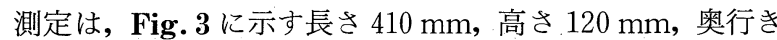
$170 \mathrm{~mm}$ の長方形チャンバー内で行なわれた。ノズルはチャ ンバー中央部にある隔壁に取り付けた．用いた熱電対線の直 径は $25 \mu \mathrm{m}$ ，長さは約 $15 \mathrm{~cm}$ であり，接点はそのほほ中央に 位置する．流れが淀んでいる位置でチャンバー内の圧力と温 度を測定し，これをノズル入口面执よび出口面での值とみな し, 剝離のない一次元等エントロピー流れを仮定してスロー 卜に打ける流速の概算值を理論的に求めた。背圧比は，これ らの圧力の比とした，試験気体は，室内からの空気とした。

測定された回復温度降下を Fig. 4a) に示す. 背圧比を 1 か ら下げると温度は次第に減少する。流速の概算值から考光る と, 本方法による流速測定は, 数 $\mathrm{m} / \mathrm{s}$ から可能であることが わかる，温度は背圧比が 0.85 以下となるとほぼ一定になる.

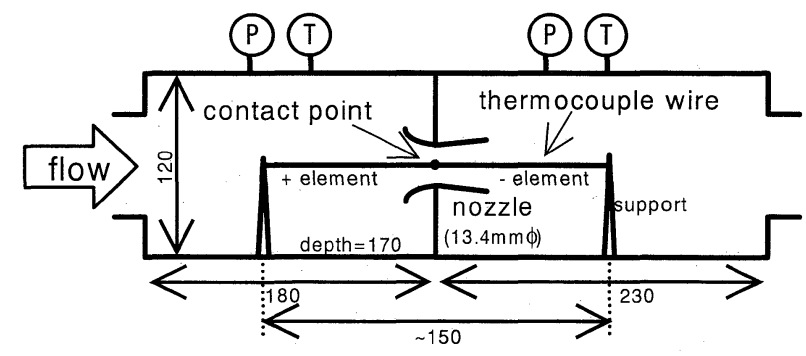

Fig. 3 Measurement setup of the recovery temperature drop at the center of the throat of the Venturi nozzle

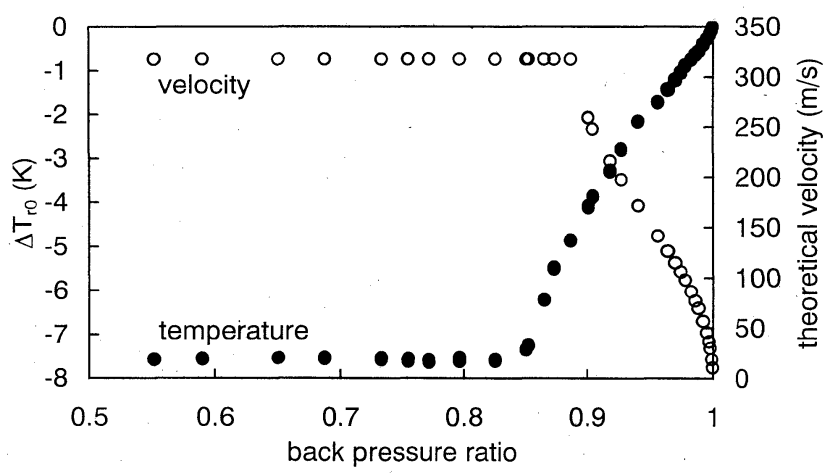

a)

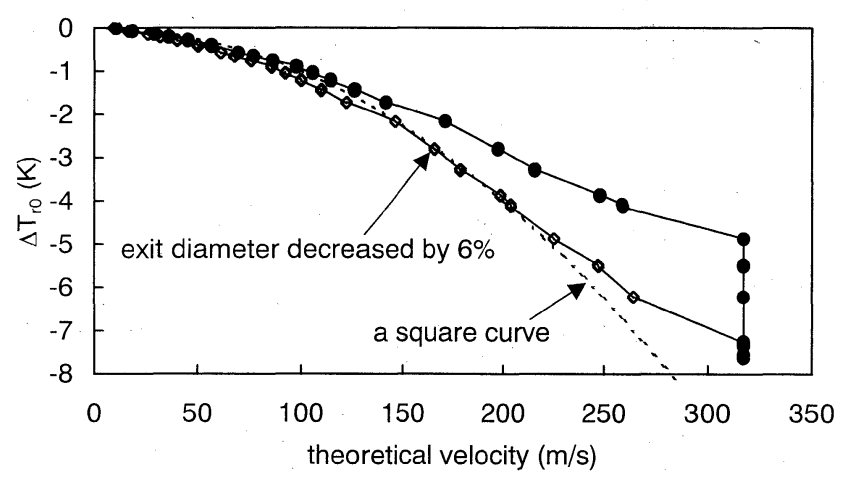

b)

Fig. 4 The recovery temperature drop measured in the setup shown in Fig. 3 is plotted against a) pressure ratio across the nozzle, and b) theoretical flow velocity at the throat calculated with the assumption of onedimensional isentropic flow. Decrement of the exit diameter by $6 \%$ to compensate the effects of the existence of the rapidly developing boundary layer and separation explains the dependence very well, in which the temperature obeys a curve of square of the flow velocity

これは，先に述べたように，ノズルが臨界したために起こっ

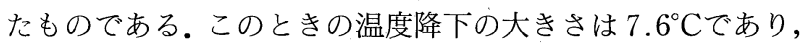
先に求めた概算值とほほ等しく, 回復温度係数は $\sqrt{P r}$ で十 分に近似できることがわかる。

剥離を考えない非粘性一次元等エントロピー流れを仮定し たノズルの理論臨界背圧比は 0.89 であるが, 実測值はこれよ り若干小さい。 その原因は急激に成長する境界層や剥離と考 
えられるが，その影響は，実質的な出口面積が幾何学的面積 より小さくなるとして近似することができる。

Fig. 4 b) は，横軸を理論流速としてプロットした回復温度 降下である。幾何学的出口面積を用いて求めた流速を用いる と，臨界音速に達してからも回復温度が変化するように見え るが，実際の流机は，図に示すように，出口直径が 6\%程度 減った場合に相当するものと考えられる。このときの回復温 度降下の流速依存性は，ほぼ自㳻の曲線に従い，(4)式が十 分に正しいことを示している。

\section{5. 音速ノズル内の回復温度分布の測定装置}

音速ノズル内に設置した熱電対線のトラバース装置は，先 の巠音速での感度測定に用いられたチャンバーに取り付けら れている。その概要と写真を Fig. 5 に示す。X方向(流れ方 向)のトラバース軸は，ノズル後方のチャンバー内にある。Y 方向へのトラバースは，このX軸に取り付けられた実効長さ $80 \mathrm{~mm}$ の腕のストロークを利用し，X 軸を回転することによ り行なう。したがって，Y方向のトラバースは直線ではなく 円弧となる。本測定では最大のストロークが $30 \mathrm{~mm}$ であるた め，X 方向のずれは最大で $1.5 \mathrm{~mm}$ となるが，流れが軸対象 であればまったく問題とならない。

ノズル前方の熱電刘サポートは，流れに与える乱れを極力 小さくするため，厚さ $1 \mathrm{~mm}$ の銅板を用いていったん下方に 曲げ，外径 $1.5 \mathrm{~mm} \phi の$ 金属管を流れ方向に薄くつぶして取 り付けた。熱電対線を訂測器に接続するためのリード線は熱 電対線と同じ材質とし，この金属管内を通した。リード線の 先端を, Fig. 6 に示すようにつぶして折り曲げ, 熱電対線はこ れにかしめて取り付けた。金属パイプから出ている $1 \mathrm{~cm}$ ほ どのリード線の弾性が, 熱電対線に起こる流体振動を抑える ために必要な張力をもたらす。

ノズル後方のサポートは前方のものと同様な構造をもつ が、これがもたらす乱机の大きさは前方のものより重要では ないため，ほぼノズル中心軸と同じ高さにある。

熱電対のリード線は，そのまま両チャンバー内から引き出 され，゙゙ジタルマルチメータの入力端子まで導かれる。温度 の值は，このマルチメータの熱電対測定機能を用い，分解能

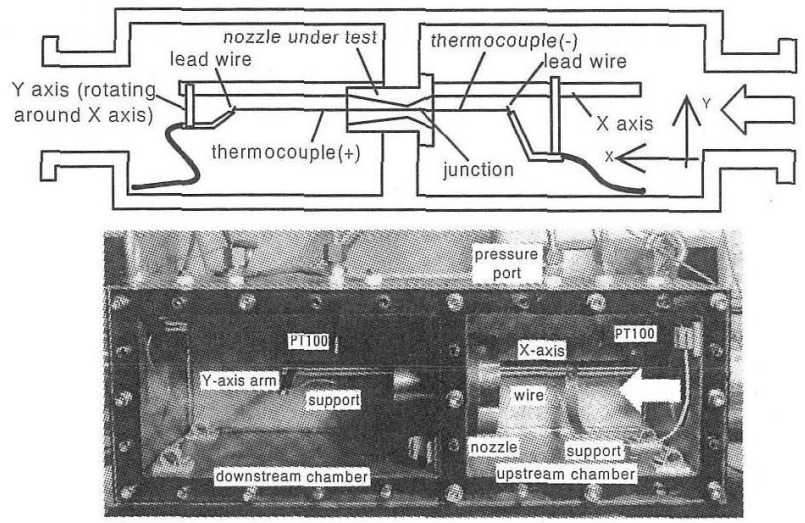

Fig. 5 The traverse chamber $0.1^{\circ} \mathrm{C}$ で測定した。よどみ点温度は，拡張不確かさは $0.1^{\circ} \mathrm{C}$ 以 下の 4 線式白金抵抗測温体で測定した。よどみ点圧力を測定

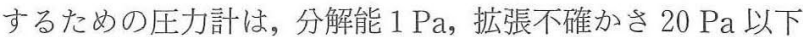
の半導体振動子式である。

本チャンバーの一面はアクリル板でできた空となってお り，チャンバーを密閉した状態で外から中の状態を監視する ことができるようになっている。

熱電対の接点位置の原点はスロート壁面上としたが，その 設定はつぎの示す手順に従った。

1. チャンバー勂をはずし，チャンバー内壁に対する寸法 管理により熱電対線をノズル軸と平行に張る。

2.ノズル入口面の真横においた望遠鏡を用い，接点をノ ズルの入口面まで移動する。

3.ノズルの設計值を用いてスロート位置まで接点を移動 する。本測定の被試験ノズルは超精密加工されたもので

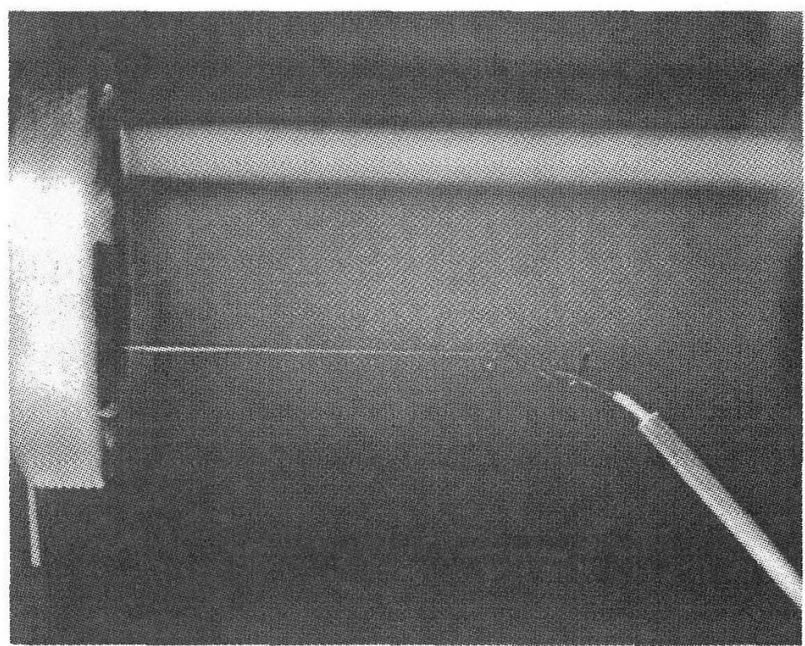

a)

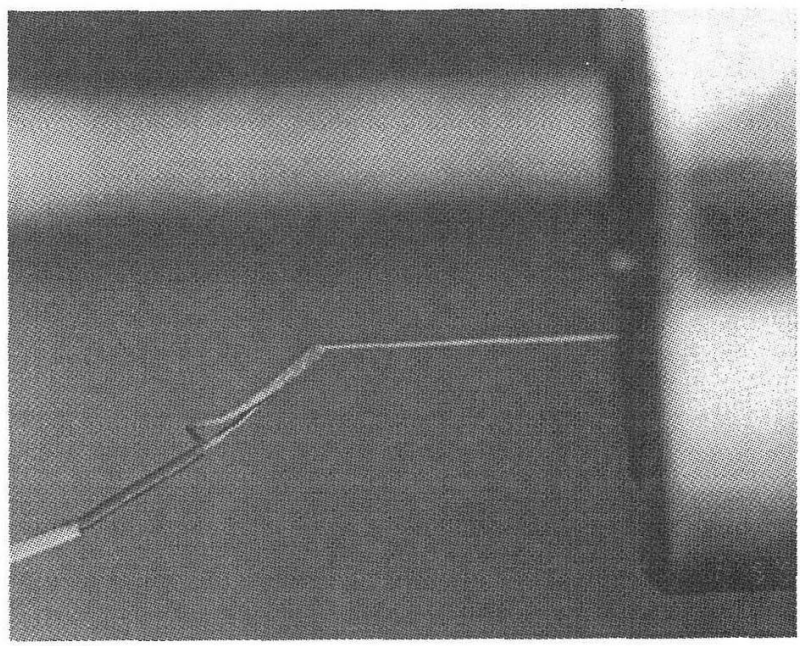

b)

Fig. 6 Photographs of the supports and the thermocouple wire of $25 \mu \mathrm{m} \phi$ taken with long time exposures of more than $10 \mathrm{~s}$ during the nozzle was choking. a) upstream, b) downstream 
あるため，製作誤差が非常に小さく，設計值を用いても 十分な精度が保たれる。

4. 空を閉めて流れを発生させ, 熱電対線に発生する微小 な流体振動が止まるまで Y 方向に動かし，その直前の位 置を原点とする。

Fig. 6 は,ノズルを臨界させた状態で露出時間を 10 秒以上 として撮影した写真である。このときの熱電刘線の太さは 25

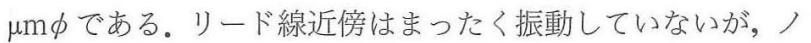
ズル近くでは微小な振動によるぶれが写っている。しかし， その振幅は線径程度以下であり，影響は無視できると考えら れる。

\section{6. 熱電対挿入による擾乱の監視}

被試験ノズルのスロート直径は $13.4 \mathrm{~mm}$ ○であるのに対

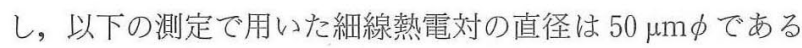
ため, その面積比は ppm オーダーとなり, 熱電対線の幾何形 状的影響はまったく無視しうる。しかし，その回りに発生す る境界層による大きな乱㞦の可能性もあるため, つぎに示す 方法で熱電対線のもたらす乱れを監視した。

すなわち, Fig.7 に示すように, 被試験ノズルの上流側に別 の音速ノズルを直列に接続して共に臨界に保ち，上流側ノズ ルを基準として被試験ノズルの流量を求め,これが熱電対線 の有無やトラバースによって変化しなければ被試験ノズル内

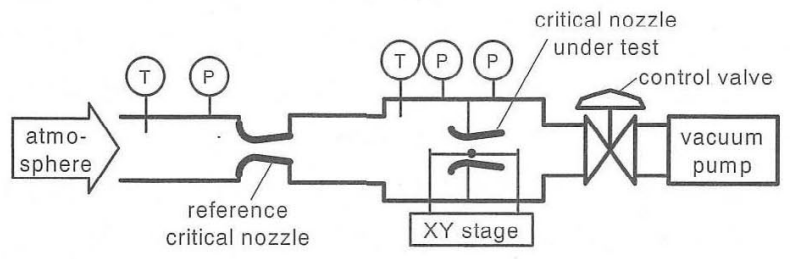

Fig. 7 Monitor of the flow rate of the downstream nozzle using a reference critical nozzle connected in series at the upstream position to detect the disturbunce of the flow field caused by the thermocouple wire and the supports.
に乱れは発生していないとみなした。この直列試験法によれ ば，下流側ノズルの 0.01\%オーダーの流量変化が安定して検 出できるため3)，流れの状態変化の検出方法としては最も敏 感なものと考えられる。被試験ノズルのスロート位置および その上流に発生した乱れは，臨界しているときの流量変化に よって監視でき，また，ディフューザ内に発生した乱れは， ノズルの臨界が崩れた直後の流量の下流圧依存性の変化に よって監視することができる.装置全体の写真を Fig. 8 に示 す。

Fig. 9 は, 四分円型ノズルを対象とし, 熱電刘線の挿入によ る流量変化の有無を調べた例である。緃軸は, 乱れがなくノ ズルが確実に臨界している状態での流量を基準とし, 背圧比 を変えたときの流量変化を相対值で示したものである。ここ で，この基準とした状態とは，すなわち，熱電対線とサポー トを取り外し，背圧比を設定可能な最低值であった約 0.2 と した状態を指す。このノズルはディフューザをもたないため, 臨界背圧比がほぼ臨界圧力比 0.53 に等しくなるはずである が，測定結果からもそのことがわかる。白丸は，ノズルの中 に $50 \mu \mathrm{m} \phi$ の熱電対線を張ったときの依存性である。両者は, 流量測定の分解能のほぼ限界に近い $0.1 \%$ 以下で一致するた

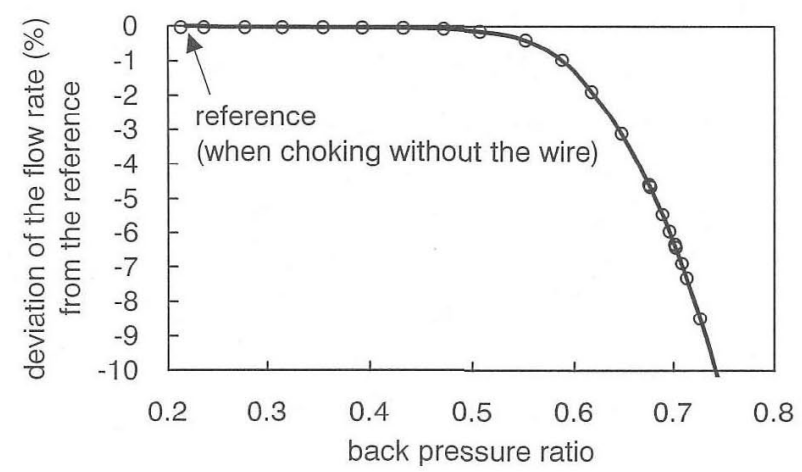

Fig. 9 Deviation of the flow rate with the thermocouple wire of $50 \mu \mathrm{m} \phi$ from that without the wire at the back pressure ratio of 0.2 . There was no deviation detected

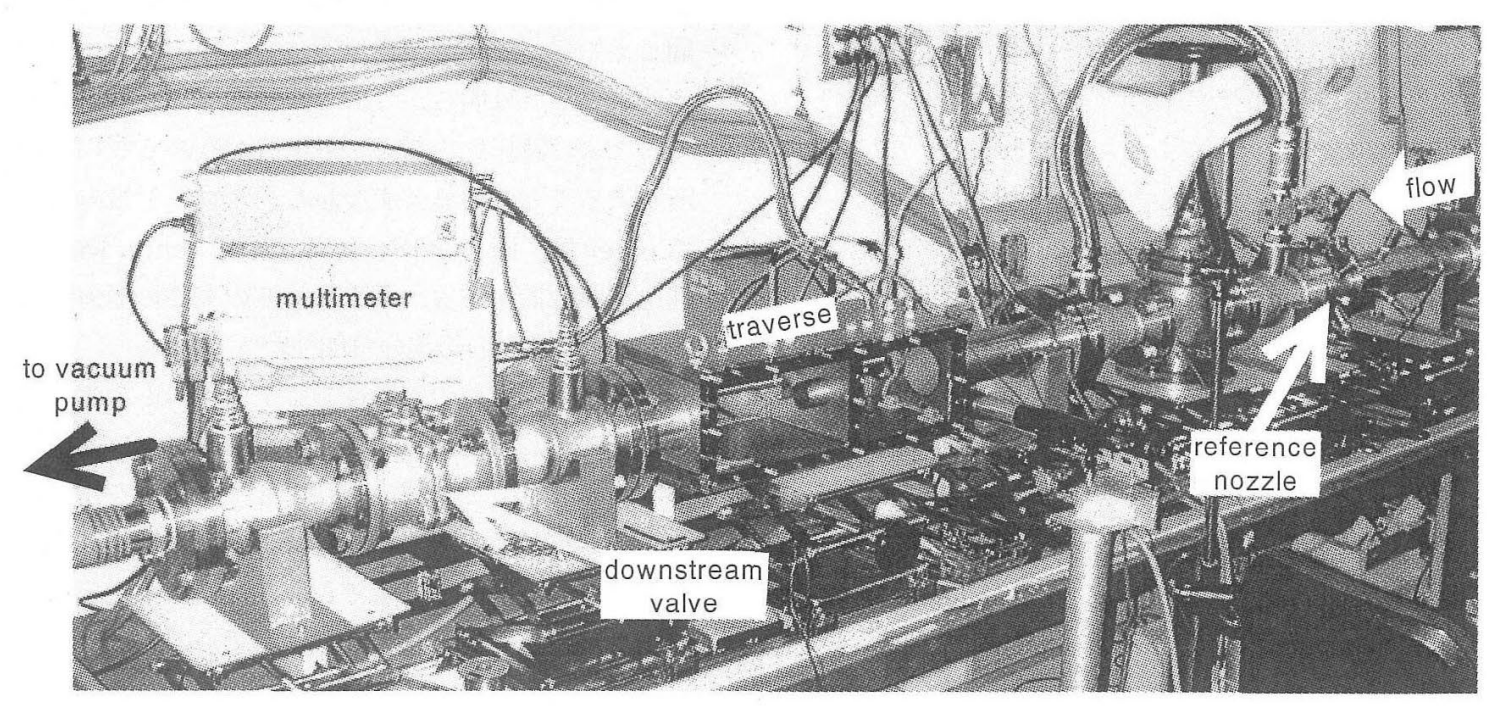

Fig. 8 Overall of the measuring steup 
め，本測定は擬似的に非侵襲であるといえる．また，熱電対 線をトラバースしても，リード線先端がノズル内に進入しな ければ，流量変化はまったく検出されなかった。

\section{7. ベンチュリ型音速ノズル内の回復温度降下分布}

熱電対線はノズルの対称軸と平行に張られるため，測定可 能な範囲がスロートに接する円筒内に限られ，スロート以外 ではノズル壁面近傍を測定することができない．測定点の例 を Fig. 10 の黒丸で示す. 以下では，ノズルの対称軸上におけ る測定を「center」，最も外側の線に沿う測定を「outer」と呼 ぶ.

Fig. 11a)は）ベンチュリ型ノズルに 0.30 の背圧比を与え たときの回復温度降下の測定結果，および，一次元等エント ロピー流れを仮定した (3) 式と (5) 式から計算した理論值で ある。上流側にはスロート直径 $6.7 \mathrm{~mm} \phi$ の基準音速ノズル が取り付けられているため, 被試験ノズルのよどみ点圧力は 約 $25 \mathrm{kPa}$ となり,レイノルズ数は $4.4 \times 10^{4}$ となった.ここ で，このレイノルズ数は，音速ノズルの分野で慣例的に用い られている臨界音速 $a^{*}$, 臨界密度 $\rho^{*}$, スロート直径 $D^{*}$ によ ぞみ点粘性率 $\mu_{0}$ を用いて求めたものである7).

$$
R e=\frac{a^{*} \cdot \rho^{*} \cdot D^{*}}{\mu_{0}}
$$

図において，測定值は細線，理論値は太線で示される。ま た， center および outer における測定は，若干太い細線で示 される. 入口面からスロート後方 $1.4 \mathrm{~mm}$ までの円環部分で は，測定された温度は滑らかに減少し，理論值と定量的にも 非常に良く一致する.スロート後方約 $20 \mathrm{~mm}$ には明白な垂直 衝撃が観測されている. 円錐形ディフューザ内における温度 変化は，垂直衝撃波が現れるまで傾向としては理論值と非常 に良く合い，ノズルの形状が円環から円錐に変わったことを 良く反映している，垂直衝撃波の直前の臨界マッ八数は，理 論值によると約 1.5 であるため, 本方法によれば, 数 $\mathrm{m} / \mathrm{s}$ か ら臨界マッ八数 1.5 を超える非常に広い範囲の遷音速流の流 速測定が可能であることがわかる.

円環部分における測定値を詳しく見ると，直径方向に分布 をもっていることがわかる.すなわち，「outer」側の温度が低



Fig. 10 Example of the measuring points
く，「center」側の温度が高い。これは，Fig. 11 b)に示すよう に, 二次元理論8) が予言する通りである.二次元理論の意味す るところを直感的に言い表わせば，壁面近傍では壁面の曲率 の影響がより大きく出て加速が大きくなり，壁面から遠くな るに従って加速が鈍る．これを回復温度で表現すれば，壁面 付近では温度が下がり, 壁面から離れるに従って温度が上昇 することになり，これは Fig. $11 \mathrm{a}$ )の測定值が示す通りであ る.

円錐形ディフューザ内では，単純な理論では予測できない 複雑な構造が発生していることがわかる．円環部分と円錐部 分の接点付近での流れの特徵は, 突然の温度上昇とその発生 点が center 側になるほど遅れる点である.これは斜め衝撃波 の特徵であり, Fig. 12 のように，三次元的にプロットすると その存在が明らかになる：この図の縦軸は，（4)式を用いて 回復温度降下から求めた流速である. 斜め衝撃波はスロート 後方 1 2 $\mathrm{mm}$ で outer 側から発生し, $6 \mathrm{~mm}$ 程度後方から center 側に大きな影響を及ぼす。この衝撃波の発生は，円環 部分と円錐部分の接点における壁面二次微係数の不連続によ る可能性が大きい.

$\mathrm{Y}$ 方向にトラバース可能な全ストロークにわたって測定 すると, Fig. 13 に示すように, 軸対象な結果が得られる。こ れは, 背圧比を 0.24 とした場合である.スロート面における 分布は，壁面に近くなるほど流速が上がり，二次元理論に良 く合うことが再確認できる.また，この測定のいかなる $(\mathrm{X}$, Y)の組み合わせに打いても流量変化が検出されなかったた め，熱電対線およびそのサポートは，いかなる位置において も乱れを発生していないことが再確認できた。

Fig. 14 は，さまざまな背圧比において測定された分布を 1 つの図にまとめたものである. 図中の数字は背圧比を示す。 0.30 の背圧比においてスロート後方約 $20 \mathrm{~mm}$ の位置にあっ た垂直衝撃は，背圧比の上昇と共に減衰しながら上流側に移 動する様子が明白にとらえられている．また，背圧比が 0.36 から 0.37 に変わると,垂直衝撃波の形状が突然不明瞭になる こともわかる．測定中においては，この背圧比でノズルから 聞こえる雑音の音色が突然変わるため, 流れに突然の状態変 化があることは明らかである．この分布一覧から明らかにな ることは, 背圧比を変えても位置が変わらない流速の減衰場 所があることである．すなわち，スロート後方 $5 \mathrm{~mm}$ の位置 で outer 側，同じく $15 \mathrm{~mm}$ の位置で center 側に定在する流 速の減衰位置がある．垂直衝撃波の突然の形態変化は，この 2 番目の構造との干渉の可能性が大きい.

本論文は本方法の有効性を示すためのものであるため，こ れ以上の流れの構造に関する解析は, 本論文の範疇外である. しかし，これまでの議論からでも，本方法を用いれば，これ まで測定不可能であった対象について，場を乱さずに流速分 布を高空間分解能で測定でき，さまざまな現象の検出，解明 に大いに役立つことを示せたはずである。 


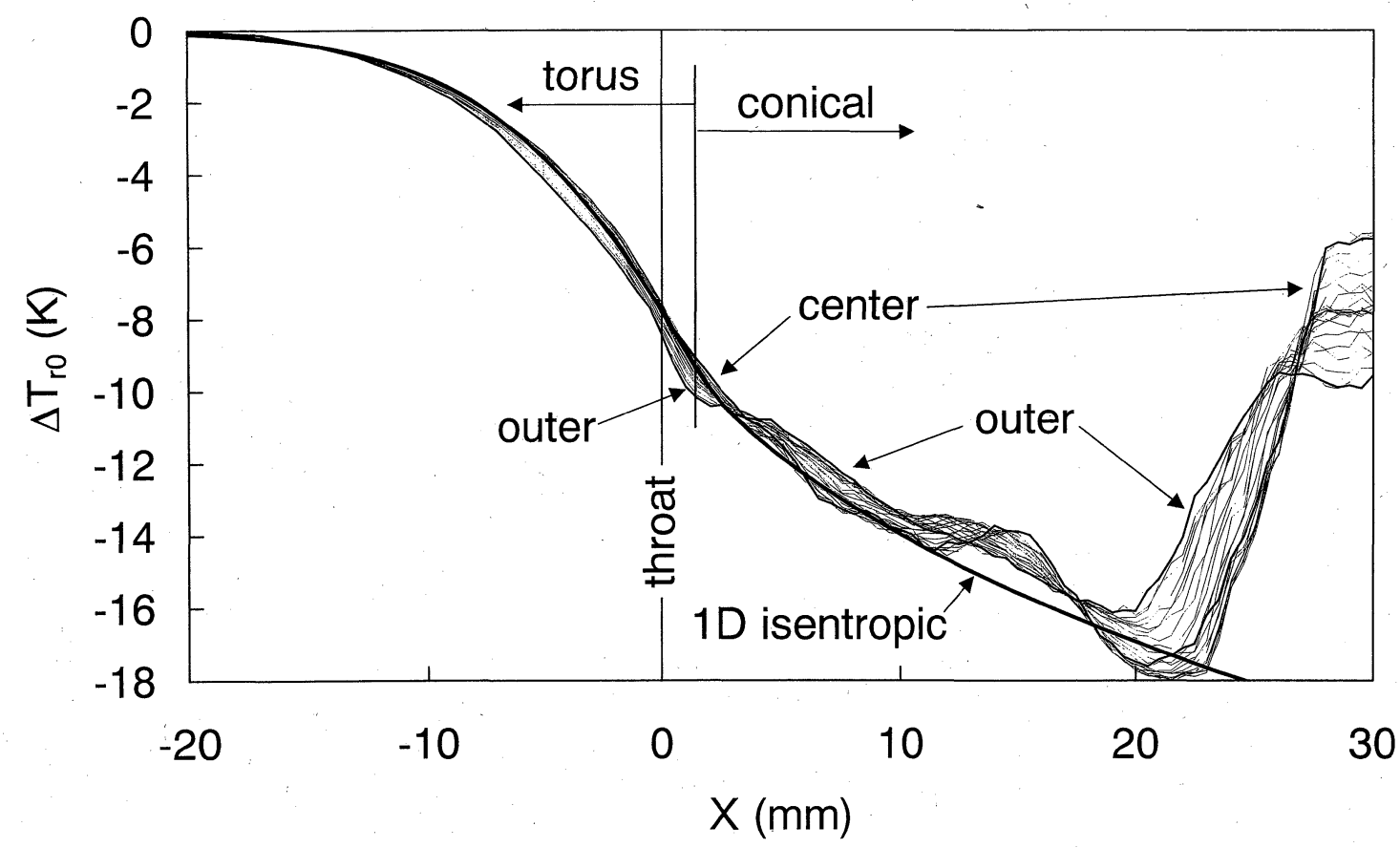

a)

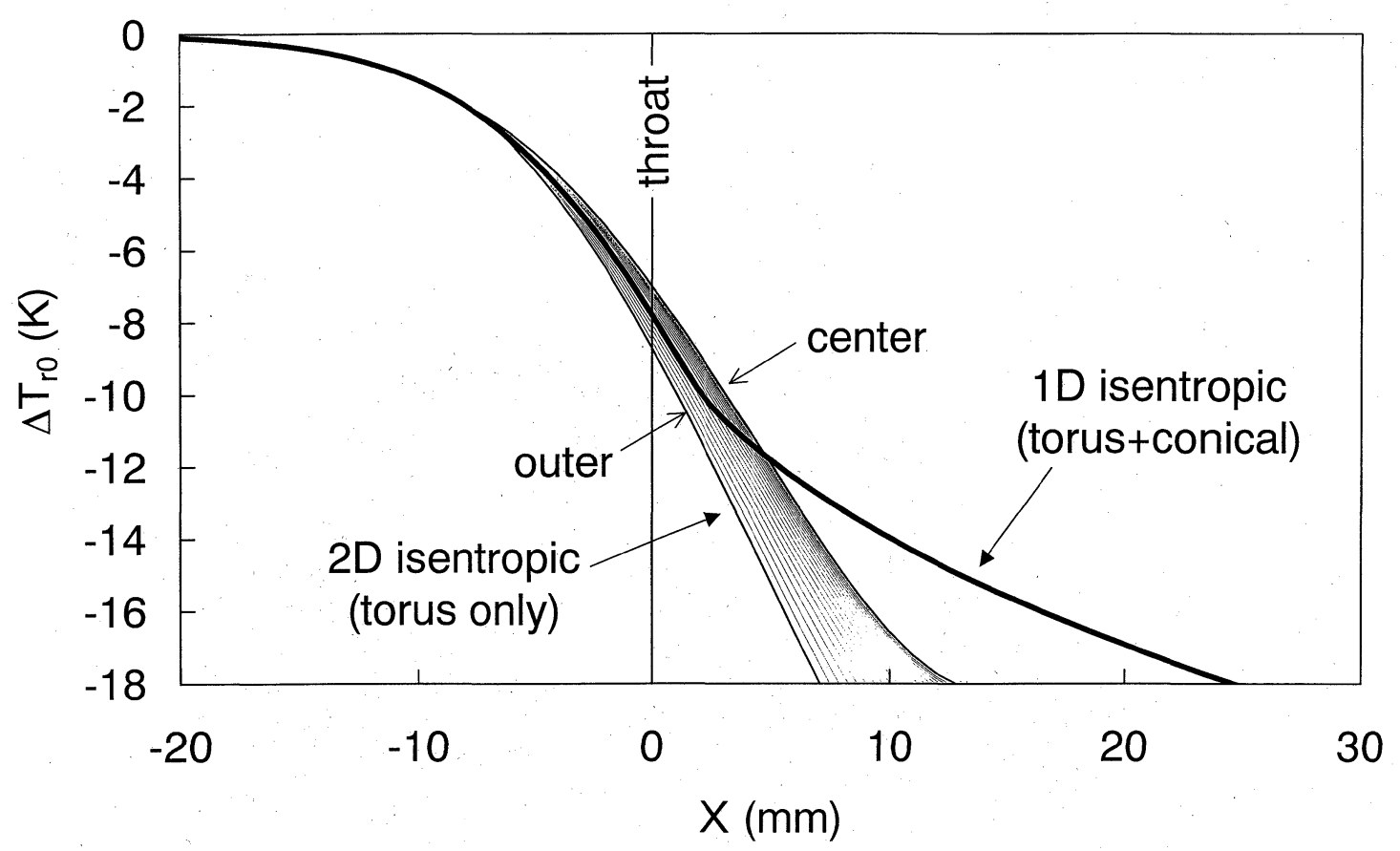

b)

Fig. 11 Comparison of the measured recovery temperature drop in the critical nozzle shown in Fig. 1 a) with the theoretical values based on one- and two-dimensional isentropic theories. The measured value agrees quite well with the one-dimensional theory as in a) togather with a fine structure predicted by the two-dimensional theory as shown in b)

\section{8. おわりに}

プラントル数が 1 でない気体の流れの中に温度センサを挿 入すると, センサ周りに境界層が発生してセンサ表面では流 速がゼロとなるにもかかわらず, よどみ点温度とは異なる回
復温度が測定される. 本論文では, この回復温度が流速に依 存することを利用し, 流速の測定が可能であることを示した.

本論文では, 回復温度の測定に細線熱電対線を用い, 流れ にもたらす乱れを極小とした。 その際, 熱電対の感度が接点 に集中しているため, 非常に高い空間分解能が同時に達成さ 


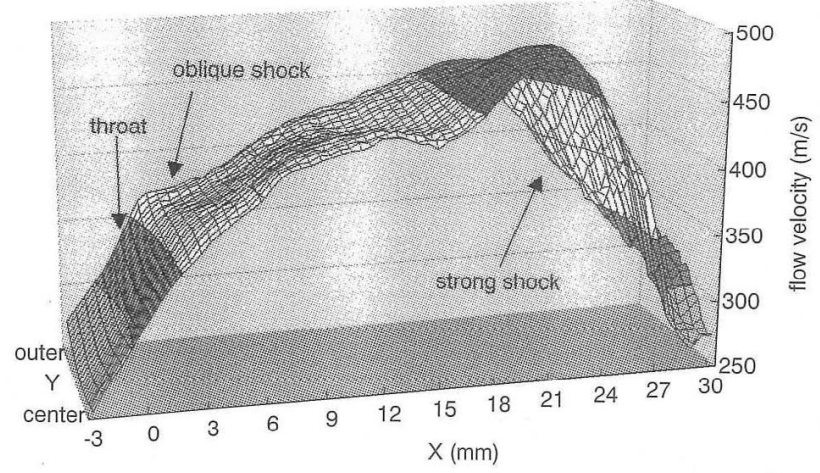

Fig. $123 \mathrm{D}$ plot of the flow velocity distribution converted from Fig. 11 using Eq. (4). The plot reveals clearly the existence of an oblique shock

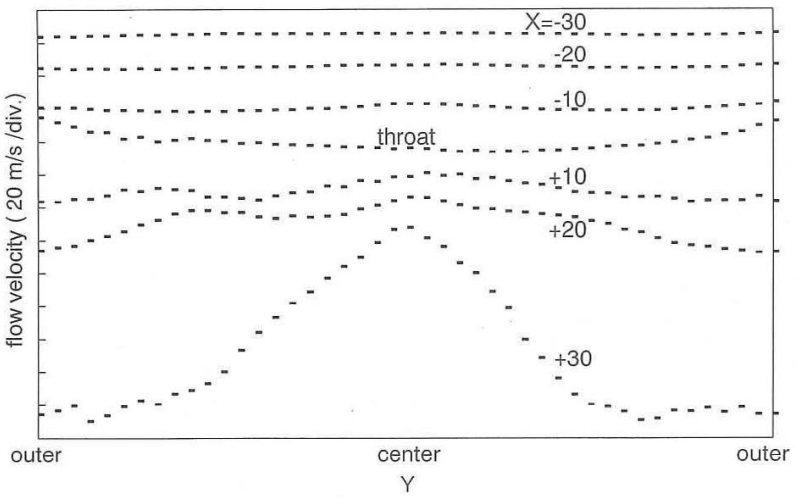

Fig. 13 Flow velocity distribution across the diameter of the measuring area at several X's. Each distribution is shifted arbitrarily to avoid overlap
れた。さらに，測定值が熱電対線の長さに依存しないため, 長い線を用いることにより, サポート位置を測定点から十分 に離し,サポートによる乱れが影響しない状態で測定できた。

本論文では, スロート直径 $13.4 \mathrm{~mm} \phi$ の軸対象音速ノズル 内に直径 $50 \mu \mathrm{m} \phi$ の熱電対線を張り，これをトラバースする ことにより音速ノズル内に発生した遷音速流速分布を測定し た。その結果, 数 $\mathrm{m} / \mathrm{s}$ から少なくとも臨界マッハ数 1.5 まで の範囲で，測定值は一次元等エントロピー理論と定量的にも 非常に良く一致するほか, 二次元理論の予測する微細構造ま でも検出できていることを示した。さらに，これらの単純な 理論では予測不可能な斜め衝撃波や背圧比と共に位置と振幅 が複雑に変化する垂直衝撃波も検出された。

以上の測定では，熱電対線の挿入やそのトラバースによる 流れ場の乱れの有無を検出するため, 上流側に別の音速ノズ ルを取り付け，これを基準として被試験ノズルの流量変化を 0.01\%の分解能で監視しながら行なった。その結果，測定中 のいかなる状態でも熱電対線がないときの流量との差が検出 されず，測定は擬似的に非侵襲であるとみなされた。

本測定法は，熱電対線を通すことができれば測定可能とな り, $10 \mu \mathrm{m}$ オーダーの高空間分解能と相まって, mm オーダー の流路でも公やモデルを用意することなくそのまま測定対象 とすることができる。また，流れ場にもたらす乱れがほとん どないため，たとえば，形状に敏感な超音速ディフューザ内 の剝離現象の解明などに有効であると考学られる。

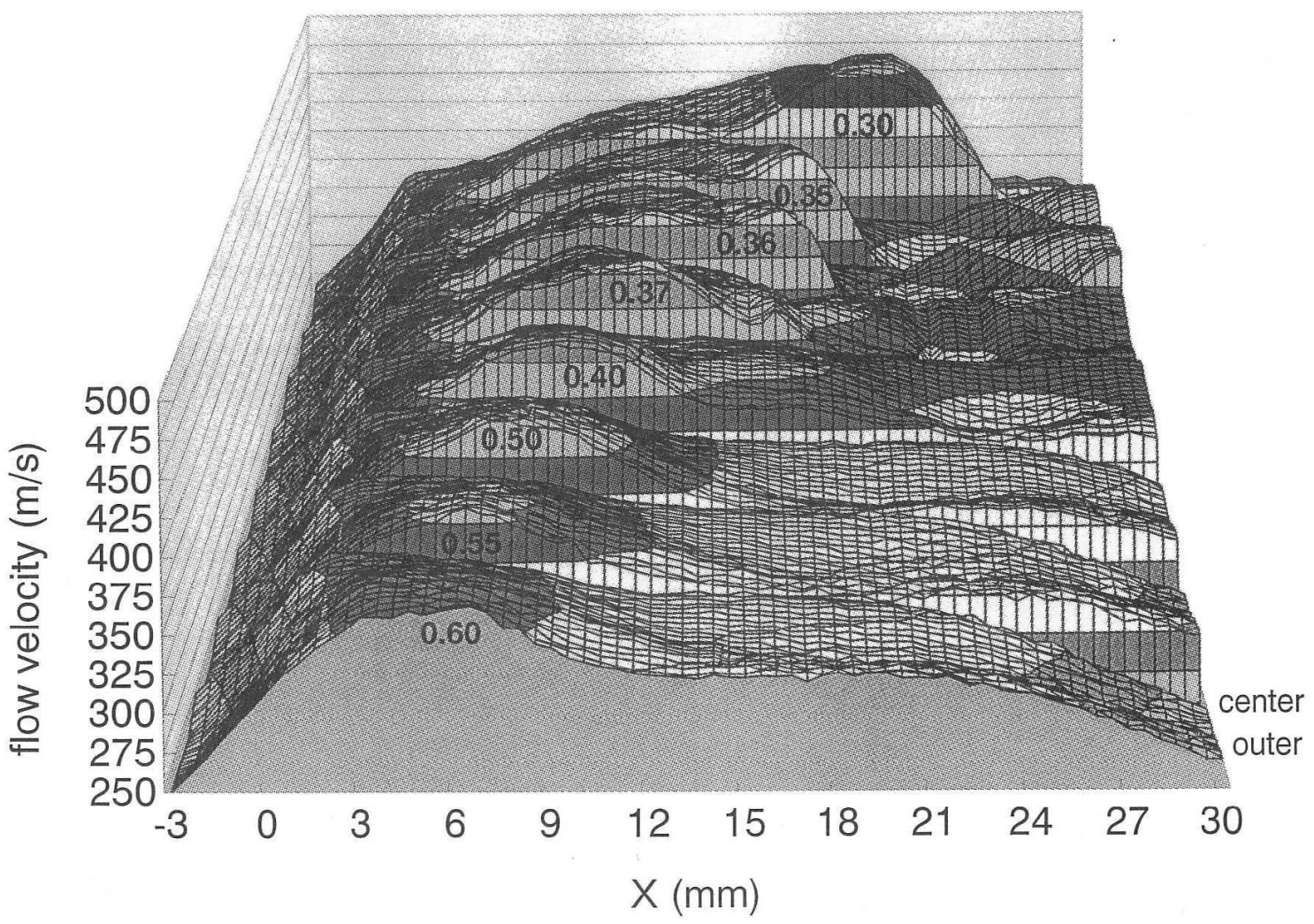

Fig. 14 Dependence of the flow velocity distribution on back-pressure ratio, which is indicated by the numbers in the figure 


\section{参考 文 献}

1) 白倉, 大橋：流体力学 (2)第 12 版, p. 223, コロナ社 (1990)

2) L. R. Tokashiki, T. Fujita, T. Kagawa and M. Takeuchi: Dynamic Characteristics of Pneumatic Cylinders Temperature Measurement of Air in Pipes, Proceedings of FLUCOME'97 325/330 (1997)

3）石橋, 高本, 中尾, 横溝：咅速ノズルの直列接続による試験と その応用, 計測自動制御学会論文集, 34-7, 698/706（1998）

4) R. J. Goldstein: Fluid Mechanics Measurements (2nd ed.), p. 108, Taylor \& Francis (1996)

5）日本熱物性学会(編)：熱物性ハンドブック, 養賢堂（1990)

6) 石橋, 高本, 中尾, 横溝: 超精密加工音速ノズルの流出係数, 計 測自動制御学会論文集, 28-12, 1411/1418（1992）

7) ISO 5168-1978 (E) : Measurement of Fluid FlowEstimation of Uncertainty of a Flow-Rate Measurement (1990)

8) I. M. Hall: Transonic Flow in Two-Dimensional and Axially-Symmetric Nozzles. Quart. Journ. Mech. and Applied Math., Vol. XV, Pt. 4, 487/508 (1962)
แ|แ-

$$
\text { ·著 者 紹 介] }
$$

石 橋 雅 裕 (正会員)

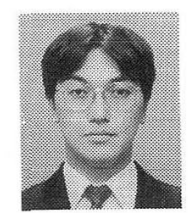

1985 年, 筑波大学大学院博士課程物理工学専攻 修了.同年通産省工業技術院計量研究所(現産業技 術総合研究所) 入所, 現在に至る. 気体流量標準の 研究に従事(工学博士)。

\section{高 本 正 樹 (正会員)}



1986 年, ロンドン大学インペリアルカレッジ Ph. D コース終了. 75 年通産省工業技術院計量研 究所(現産業技術総合研究所) 入所, 現在力学部流 体計測研究室長. 日本機械学会, 日本流体力学会, 可視化情報学会などの会員 (工学博士). 